\title{
ATTITUDE, ANXIETY, HUSBAND SUPPORT, AND INTRA UTERINE DEVICE USE AMONG WOMEN OF REPRODUCTIVE AGE IN MOJOKERTO, EAST JAVA
}

\author{
Rindra Deviasti'1), Eti Poncorini Pamungkasari²), Bhisma Murti') \\ 1)Masters Program in Public Health, Universitas Sebelas Maret \\ 2)Department of Public Health, Faculty of Medicine, Universitas Sebelas Maret
}

\begin{abstract}
Background: Intra uterine device (IUD) is one of the most popular contraceptive methods, especially for long-term reversible contraception, as it can be easily fitted and removed. While the IUD is a safe and cost-effective method, however, its use is very low in some countries, and the reasons for this are not well understood, especially in Mojokerto, East Java, Indonesia. The purpose of this study was to examine the effects of attitude, anxiety, husband support, on intra uterine device use among women of reproductive age in Mojokerto, East Java.

Subjects and Method: This was a case control study carried out at Gondang community health center, Mojokerto, East Java, from April to May 2018.A sample of 225 women was selected for this study by fixed disease sampling, consisting of 75 IUD users and 150 non-IUD users. The dependent variable was intra uterine device (IUD) use. The independent variables were attitude, anxiety about side effect of IUD, and husband support. The data were collected by questionnaire and analyzed by a multiple logistic regression.

Results: IUD use increased with positive attitude $(\mathrm{OR}=3.87 ; 95 \% \mathrm{CI}=1.92$ to $7.83 ; \mathrm{p}<0.001)$ and low anxiety $(\mathrm{OR}=2.08 ; 95 \% \mathrm{CI}=1.09$ to $3.97 ; \mathrm{p}=0.026)$. IUD use decreased with low husband support $(\mathrm{OR}=0.19 ; 95 \% \mathrm{CI}=0.09$ to 0.37 ; $\mathrm{p}<0.001$ ).

Conclusion: IUD use increases with positive attitude and low anxiety, but decreases with low husband support.
\end{abstract}

Keywords: intra uterine device, attitude, anxiety, husband support

\section{Correspondence:}

Rindra Deviasti. Masters Program in Public Health, Universitas Sebelas Maret. Jl. Ir. Sutami No. 36 A, 57126, Surakarta, Central Java.

Email: widodarigunung@gmail.com. Mobile: +6281331301065 